\title{
Cornering the Canvasser: Amnesty International USA Maria Drivenes and Herbert Sherman Long Island University - Brooklyn
}

\author{
Maria Drivenes \\ Graduate of LIU-Brooklyn's MS program in Human Resource Management and an \\ inductee into Sigma Beta Delt, USA \\ Herbert Sherman Ph.D \\ Full Professor and Chair of the Department of Business, Long Island University - \\ Brooklyn Campus, USA
}

Received: Feb. 22, 2018 Accepted: Mar. 28, 2018 Online published: Mar. 29, 2018

doi:10.5296/jpag.v8i1.12683 URL: https://doi.org/10.5296/jpag.v8i1.12683

\begin{abstract}
The following is an instructional, disguised field-based case study that was written for an introductory course in human resource management although the case could be utilized in either an introductory management or business ethics class. Primary data from the case was retrieved from an informal interview with a former employee at Amnesty and extended via secondary research from relevant internet sites. The case focuses on several major human resource issues in terms of wearing symbols of faith at work and negligent hiring. It also indirectly raises questions of using personality tests in recruiting and leadership training.

The story line is as follows: Aida, a recent college graduate, was having little success obtaining second interviewees after three months in the job market. She conducted some online research to firm the "perfect" organization to work for which was Amnesty International USA (AI USA).

Applying and successfully hired for a canvasser position, Aida struggled to hit her weekly-required collection quota of $\$ 125 /$ week. Her team leader Luke finds the situation frustrating and starts to believe that Aida's hijab is getting in the way of her performance based upon his perception of donor discrimination.

The situation becomes convoluted when Luke, in the process of assisting Aida sign up a donor (Luke's main concern), overheard a conversation between Holly (an excellent and experienced canvasser) and a potential donor leading Luke to suspect Holly of committing
\end{abstract}


theft and fraud. The case ends with a series of questions about using symbols of faith at work, personality and job fit, and job descriptions/specification.

Keywords: faith symbols, negligent hire, job descriptions, personality tests

\section{Introduction}

"Go find yourself a real job and stop standing here begging innocent people for money, you idiot!" It was early Thursday morning of Aida's first week on site as a canvasser for Amnesty International USA (AI USA) and the week was ending much tougher than she ever imagined. She could not wrap her head around how unkind people could be, and ironically was debating with herself if being yelled at was actually better than being just being completely ignored, the more normal response. So far this week she had one "almost" donor; unfortunately, when she was going to scan the potential donor's credit card the payment device blacked out, and eventually so did the contributor. Canvassers must hit their quota of $\$ 125$ of donations a week in order to keep their job. She finished work completely exhausted and was afraid that the next day, Friday, would be more of the same. Aida understood that she did not seem to be a good match with the job and started wondering if it was a worthy call for AI USA to hire her in the first place. Her thoughts wandered as she recollected how she ended up in this "mess."

Her revelry was abruptly interrupted by Luke her team leader. He approached her saying that unless she hit her quota for next week she would be put on review and then the following week, if she continued not to obtain donations that met the quota, fired. Aida knew that tomorrow would most probably end in tears, just like the prior days in the week.

\subsection{Prequel: In Search of the Perfect Organization and Job}

Having been unemployed for over three months after graduating with an undergraduate degree in international affairs from a prestigious U.S. liberal arts college, Aida started to believe her hijab ${ }^{1}$ might have had something to do with her declining success at obtaining second interviews. She was articulate, an excellent writer, hardworking and very personable and looked great on "paper" but was also shy and, after a few "failed" interviews, lacking self-confidence.

Aida decided that maybe she should take a different approach to job searching and try to find and organization that fit her values and philosophy as well as an organization that would be quite sensitive to her religious orientation and needs. After surfing the internet a little bit and looking for what she would later characterize as her "dream" organization to work for, Aida perused AI USA's website and was highly moved by the organization's vision.

\section{Our Vision for Change}

All people have fundamental human rights. But those rights are abused or denied every single day. When that happens, Amnesty International finds the facts, exposes what's

\footnotetext{
${ }^{1}$ The traditional covering for the hair and neck that is worn by Muslim women. (https://www.merriam-webster.com/dictionary/hijab, 12/7/17)
} 
happening, and rallies people together to force governments and others to respect everyone's human rights.

And we get results. Last year alone, Amnesty International helped free 153 people who were wrongfully imprisoned because of who they are or what they believe - and we changed laws in dozens of countries on refugees, reproductive rights, LGBT equality, free speech, the death penalty, and other critical human rights issues.

From start to finish, our work focuses on the individual-people whose human rights are abused, and people who have the power to change the world. We received the Nobel Peace Prize for our life-saving work.

Amnesty International is a global movement of millions of people demanding human rights for all people - no matter who they are or where they are. We are the world's largest grassroots human rights organization. (https://www.amnestyusa.org/about-us/, $1 / 24 / 18)$

Aida did some background research on Amnesty International and discovered that Amnesty International (AI) was founded by the British lawyer Peter Benenson in 1961 and in 2017 had more than 3 million supporters, activists and volunteers in more than 150 countries. The organization works to protect human rights worldwide wherever justice, freedom, truth and dignity are denied. Amnesty International USA has nearly 250,000 members and is the largest country section of AI. Amnesty has a diverse workforce and perceives themselves as an Equal Opportunity Employers; they especially encourage women and minorities to apply for available positions. (https://www.amnestyusa.org/about-us/who-we-are/, 1/24/18)

She immediately went to their "Work with Us" website (see Appendix 1, General Advertisement: Amnesty Internal USA) for further information. She followed the links to "Amnesty International Regular Vacancies" and found that the only job she seemed qualified for was "canvasser." She immediately clinked on the link "Apply for this Role", created a personalized account, and then applied for the position that included completing a rather detailed on-line application form. The job paid fairly low (starting just above minimum wage) with no benefits listed but in six months would pay $\$ 17 /$ hour. Living with her parents and still covered by their medical insurance, she felt as a "starter" job in such a wonderful organization it was worth the sacrifice. The next level up from her job, team leader, could make a respectable salary of \$37.5 K. (See Appendix 2, Job Description: Canvasser.)

She did not expect to hear back from them since "only qualified candidates will be contacted by AIUSA staff” (See Appendix A, General Advertisement: Amnesty Internal USA) and was surprised to be called in for her first interview. She was bubbling with enthusiasm during her visit to AI USA and evidently, that came across well since a week later she got a call back to come a second time. The second meeting was actually allot of fun - her interviewers (team leader Luke, Director of Canvassing Mr. Clark and team member Holly) were very intrigued by her education and background since she possessed a pretty thorough knowledge of international affairs as it related to AI USA's mission. They discussed world affairs, the impact of the Trump presidency on the world's view of the US and more specifically the continued 
need to expand AI's outreach to those in most need of having their voices heard.

Two weeks elapsed (it seemed like eternity to Aida) but she was thrilled when she was offered the job at AI USA and immediately accepted. Finally having a job, she could start saving money to get her own place and be at least somewhat financially independent. Her mom was so proud of her that she made a huge dinner party and invited friends and family to celebrate her success; so now the last thing she wanted was to come home and tell all of them about her failure.

\subsection{Luke - Team Leader}

Luke, the team leader was a young person who had recently entered this position and possessed limited managerial experience. Luke (in his late 20s) began as a canvasser and from the start was a quick learner. Luke considered himself an outgoing, handsome man who in his view charmed all the people he came across, especially women in their 40s. He had only been in AI USA 4 months yet he felt he was ready for the position of team leader. Then after one-year of hard work and hustling, he got his team of four canvassers. His ambition though was to become the Director of Canvassing in New York, and he knew that in order to do so his team had exceed, not just hit, their weekly quotas.

Why did he want the Director's job? Besides the obvious raise in pay and prestige, Luke knew it was the Director of Canvassing in NYC who on a weekly basis reviewed all job applications. The Director then chose twenty finalists out of amongst the 200 or so candidates who applied. The team leadership then interviewed these candidates and conducted their first week of on-the-job training ${ }^{2}$

He had at least one plan behind those dreams. The day he would become director, the first thing he was planning to do was to go straight to Human Resources and have them change their non-existent job requirements for canvassers. Right now, the only requirement needed was the ability to interact with people, though he was not sure everyone hired was able to do even that! He would also implement a personality test because approaching people on the street, cold canvassing, took a very specific outgoing personality type.

\section{Having it Covered or Cover-up? A Meeting with Mr. Clark}

Friday the next morning Luke was sweating in the meeting because his boss Mr. Clark was not happy with Luke's team numbers for the week. Mr. Clark knew that Luke had been an excellent and enthusiastic canvasser and AI USA managers thought that he would make an excellent "street" supervisor. They gave him a field promotion after his first year of successful canvassing and Mr. Clark inherited him as one of his numerous team leaders. Mr. Clark was less than thrilled with taking a successful canvasser and making him a supervisor ("why take away a great fundraiser - makes no dollars or sense!'). He voiced his concerns with the Director of Canvassing but the Director overrode his objections.

${ }^{2}$ Prior, M. (June 8, 2017). Interview with previous employee at Amnesty International, NY Office. 
Luke realized that he had several challenges as an untrained field supervisor and that he knew deep down that he should have told Mr. Clark about the current situation with his team. He struggled with what to tell Mr. Clark because he felt that if he talked about his qualms about most of his team members Mr. Clark would replace him (or demote him back to canvasser) and not them. Canvassers came and went but team leaders had a chance at moving up the organization. Therefore, when Mr. Clark asked him what he would do differently next week Luke told him not to worry because he had it covered and would show better figures next Friday.

Yet the cards seemed stacked against Luke. For one, he received from Human Resources a new canvasser named Aida who, after a few days on the job, had not obtained even one donation. After observing her canvassing approach he was wondering about how to 'make her' perform well; certainly to help her make her first "sale" (obtain her first donation). He had mixed feelings over whether her headscarf was playing a role in deterring donors and wanted to talk to Aida about it. He had observed how potential donors that he knew he could have "closed"3 reacted to Aida and thought her attire put them off. He wanted to ask her to take it off because he thought that could lead to more donations. He had to admit to himself though that he was not looking forward to that conversation with her and held off talking with her until he absolutely felt that he had to.

He had also almost given up on Tim, another canvasser from his team. Tim was the laziest person he had ever met, earned just enough to keep from being fired, forcing Luke to obtain some new team members every few weeks so he could meet his team's quota. Kevin, on the other hand, who started at the same time as Aida, had a good jump on things and showed some real talent. He thought that Kevin would be the next team leader and allowed him to help try to motivate Aida and Tim.

Holly, another canvasser on his team, was a mystery - an unsolvable puzzle. She seemed remarkable at approaching people and engaging them in conversation, however, she never brought a big donation to the table. She hit her quotas every week of $\$ 125$, but never a penny more and she had yet to get a donation of over $\$ 20$ a month, which is unusual for a person who that easily gets people to sign up. In the beginning Luke did not care that much as long as she hit the quotas but studying the results of the other group members it seemed somewhat odd that she always had the same donor pattern, contrary to the others who obtained somewhat varying results week in and week out. Since she was always managing to stop people and have conversations, Luke never made it his priority to listen to her conversations, mostly because he was rather busy with helping the newest canvassers.

Luke had become so annoyed with Human Resources for hiring such a shy person as Aida (who probably was afraid to talk to herself) that a self-driven, self-managed person like Holly was a pleasure. Holly had mentioned on several occasions that she wanted some privacy when signing new members and would very often bring them a bit further away, even around the corner out of ear and eyesight. Luke was okay with that since it did produce results.

\footnotetext{
${ }^{3}$ A slang sales term for making a sale. In this case obtaining a donation.
} 
In total, the team was not performing sufficiently and Luke had to take some action by addressing his weakest link. Luke decided right then to take action - he would have to talk to Aida about the headscarf at the end of the day's shift.

\section{Around the 'Shady' Corner}

It was toward the end of the day and Luke finally mustered up enough courage to talk with Aida. Just as he was about to broach the subject of her hijab he saw that she was fumbling with trying to process what looked like a donation using her charge card phone attachment. When Aida's payment device stopped, she called for him to help and he immediately ran over to assist. Of course, lamented Luke, this was Aida's first member and of course, the payment device had to stop working. Just Aida's luck! He ran around the corner to where Holly was talking to a potential donor to see if he could borrow her charge card device. He thought, "no way is Aida not getting this donor. Now, it would be more convenient though if Holly could have been standing next to us." Luke was mumbling other less complimentary thoughts to himself as he turned around the corner.

"Yes, correct," said Holly to the potential donor. "Twenty dollars cash as a membership fee and then you can register your payment method for a monthly charge on my device here. And again, thank you so much for becoming a member at Amnesty International, you made an excellent choice." Holly felt so relieved to get this signing, and was trying not to let it shine through her voice; this one had been a tough one. "Is your payment device working?" Luke said as he approached her. As she turned and saw Luke, and she was shocked. How long had he been standing there? What did he hear or see? Holly started stumbling but could not seem to find any words. Growing up her mom used to tell her "that she had a mouth full of words" because she could never stop talking, until just now. "The one Aida had just blacked out, just finish up your signing and come back to us, okay?" said Luke in an exasperated voice. "Um, yes" Holly said with an expression on her face like a newborn baby - as innocent and white as snow.

On his way back to Aida, Luke stopped. What did she say to the customer? Did she say cash? First, what membership fee? Second, they had new tech devices so people did not need cash to sign up! People hardly ever carry cash and there was no membership fee whatsoever. Luke choked on the thought of what might be going on and he knew he would have to talk with Holly after he helped with Aida's donor. Coming back to Aida, he saw the disappointment in her eyes. In fact, it looked like she would start crying any moment. Her potential donor had taken off and Luke was sure that Aida did not obtain a donation.

The potential donor was not the only one to leave Amnesty International that day. Once Luke left, Holly immediately took off from the area and never came back. She was a no show to work on Friday (payday) and by next Monday, Luke wrote her off as MIA (missing in action).

Meanwhile Holly was upset that her "gig" was up and she missed her last paycheck but was just happy that she had made allot of extra cash that week. She knew getting a new job was not easy given her work history of "borrowing" from her previous employers. AI was not the first organization to hire her without a background check and she knew they clearly would not be 
the last - there is a sucker born every minute! ${ }^{4}$

\section{Suggested Case Questions}

1. What is your opinion as to Aida's approach to job searching? What would you have done in her place and why?

2. If Aida received a personality test based upon the "Big Five" theory of personality, where do you think she would score highest/lowest? Is her personality a good "fit" for a canvasser? Why or why not.

3. Examine the summary, responsibilities, education, experience and skills required for a canvasser (Appendix 2). Do you agree that these are appropriate for a canvasser? Does Aida fit the current job description/specification? If you disagree, what would propose and why?

4. Discuss the legal and moral issues surrounding symbols of faith at work. Can Luke legally ask Aida to take off her hijab? Regardless of legalities, how would this action fit in with AI USA's mission?

5. What is negligent hiring and how does it apply to this case? How reliable are background checks in reducing negligent hiring?

\section{Appendix}

Appendix 1. General Advertisement: Amnesty Internal USA (https://careers.aiusa.org/, $1 / 24 / 18)$

\section{Employment / Internship Opportunities with Amnesty International USA}

Thank you for your interest in employment opportunities at Amnesty International USA. Recruitment activities for regular paid positions in the United States are coordinated through the Human Resources Department in New York. Amnesty International is an Equal Opportunity Employer, committed to diversity in the workplace. Women and minorities are encouraged to apply for opportunities that are available. In general, we accept resumes for available positions only. Current vacancies will appear on this site.

Please note: When you submit your application, you will receive an automatic reply confirming receipt of your application. Due to high volume, AIUSA cannot provide additional confirmation that resumes or other application materials have been received. Only qualified candidates will be contacted by AI USA staff.

Appendix 2. Job Description: Canvasser (https://careers.aiusa.org/vacancy/ canvasser-0273/299/description/, 1/24/18)

\footnotetext{
4"There's a sucker born every minute" is a phrase closely associated with P. T. Barnum, an American showman of the mid-19th century, although there is no evidence that he said it. Early examples of its use are found instead among gamblers and confidence men. (https://en.wikipedia.org/wiki/There\%27s_a_sucker_born_every_minute, 1/30/18).
} 


\section{Macrothink \\ Journal of Public Administration and Governance \\ ISSN 2161-7104 \\ 2018, Vol. 8, No. 1}

Canvasser (0273)

Summary: Our canvassers persuade the general public to support Amnesty International USA's (AIUSA) mission. Canvassers work in public spaces informing people about our work and inspiring them to support us as members. This is a full-time paid position (35 hours per week) working directly for AI USA. Opportunities for advancement are available. Base pay starts at $\$ 13 / \mathrm{hr}$. for the first 2 weeks of training, after 2 weeks $\$ 15 / \mathrm{hr}$. and after 6 months $\$ 17 / \mathrm{hr}$. Team leaders can make up to $\$ 37.5 \mathrm{~K}$ annually.

\section{Responsibilities}

- Distribute information about Amnesty International's mission.

- Represent a positive image of AIUSA to the public.

Requirements Education and Experience:

- Roles requiring strong communication skills a plus.

- Sales experience good, but not required.

Skills:

- Strong interpersonal skills

- Positive energy and attitude

- Interest/ passion for human rights issues and AIUSA's mission

- Motivated and driven

To Apply: Send an e-mail to one of the addresses below with 'Canvasser Application' as the subject line. Include a resume in the body of your email and a short (no more than 1 paragraph) introduction to yourself and why you think you would be a good fit. Please be sure to include a current phone number and email. Successful applicants will be contacted within 2-3 days.

Amnesty International USA is an equal opportunity employer strongly committed to diversity and inclusion within the workplace. Women, People of Color, LGBTQIA individuals, and other historically disenfranchised populations are encouraged to apply.

Cornering the Canvasser: Amnesty International USA Abbreviated Instructor's Notes (Do Not Distribute)

\section{Case Description}

This is a field-based disguised case that was written for an introductory course in human resource management although the case could be utilized in either an introductory management or business ethics class. Primary data from the case was retrieved from an informal interview with a former employee at Amnesty and extended via secondary research from relevant internet sites. The case focuses on several major human resource issues in a humanistic not-for-profit organization including wearing symbols of faith at work and negligent hiring. It 
also indirectly raises questions concerning the use of personality tests in recruiting and leadership training.

The case has a difficulty level appropriate for a junior level course in human resource management, business ethics, or principles of management. The case is designed to be taught in one class periods (may vary from fifty-five minutes to eighty minutes depending upon the course structure and the instructional approach employed) and is expected to require between four to six hours of outside preparation by students.

\section{Case Synopsis}

Derived from observation, field interviews and secondary research the case describes Aida, a recent college graduate, who was having little success obtaining second interviewees after three months in the job market. She conducted some online research to firm the perfect" organization to work for which was Amnesty International USA (AI USA). Applying and successfully hired for a canvasser position, Aida struggled to hit her weekly-required collection quota of $\$ 125 /$ week. Her team leader Luke finds the situation frustrating and starts to believe that Aida's hijab is getting in the way of her performance based upon his perception of donor discrimination. The situation becomes convoluted when Luke, in the process of assisting Aida sign up a donor (Luke's main concern), overheard a conversation between Holly (an excellent and experienced canvasser) and a potential donor leading Luke to suspect Holly of committing theft and fraud. The case ends with a series of questions about using symbols of faith at work, personality and job fit, and job descriptions/specification.

\section{Research Methodology and Data Collection}

The first author in this case interviewed one of the case characters (although not the subject of the discrimination) hence this research is subjective and phenomenological in nature although supported by secondary research. The writing style of the case therefore reflects a more colloquial style then one might find in a typical business case and therein tries to capture the points of view of the various case characters. The first author, through personal reflection, observations, e-mails, and discussions with the key characters in the case as well as through secondary research collected the information for this case. The quotes presented in this case are paraphrases of actual conversations between the case characters as told by a third party.

\section{Instructional Audience \& Placement in Course Instruction}

The case should be introduced after students have read material on discrimination, employee recruitment, job analysis, negligent hiring, psychological testing and symbols of faith at work. Since the case covers numerous chapters in a typical HRM textbook, and has many confounding elements, it is recommended that the case be employed as a sectional or comprehensive case rather than an end-of-chapter case. (Byars and Rue, 2006)

In its secondary uses, the case could serve as an end of chapter case dealing with HRM issues in an introductory management course or could serve as a introductory or end of chapter case

\footnotetext{
${ }^{5}$ An excellent discussion of phenomenological research is provided by Stan Lester at http://www.devmts.demon.
} 
dealing with employer-employee relations in a business ethics course. (Dubrin, 2006; Jones and George, 2006).

\section{Learning Objectives}

The overall purpose of this case is to introduce students to the numerous human resource (HR) management issues that are experienced by first line supervisors (non-human resource professionals) who have to manage their employees within the confines of HR law as determined by their HR office. Students obtain a "real-world" feel of the situation through character dialogue and tacitly experience some of the difficulties that the characters encountered when trying to work for a nonprofit firm with a humanitarian. Specific learning objectives are as follows:

- For students to understand the idiosyncratic nature of managing a not-for-profit organization whose supervisor does not seem able to apply their mission to how employees are treated.

- For students to obtain a basic understanding of the human resource concepts of discrimination, employee recruitment, job analysis, negligent hiring, psychological testing and symbols of faith at work.

- For students to discern what actions Amnesty International could have taken to prevent negligent hiring and the seeming mismatch of employee skills and job requirements.

- For students to determine what actions Amnesty International can take in the future to prevent potential discriminatory actions from occurring.

\section{Teaching Strategies}

\subsection{Preparing the Student Prior to Case Analysis}

There are several approaches, none of which are mutually exclusive, that an instructor may employ in terms of utilizing this case. It is strongly recommended that, regardless of which course this case is to be employed with, students should have some exposure to antidiscrimination law. Some background information can be gleaned from such websites as http://www.eeoc.gov/types/race.html (EEOC's definition of race discrimination), http:// www.eeoc.gov/facts/qanda.html (discriminatory practices), http://www.usdoj.gov /crt/emp/faq.html (the justice department's site on frequently asked questions) and http: //www.lawzilla.com/content/fed-emp-300.shtml (facts about EEOC mediation).

Secondly, it is also recommended that students have some grounding in employee standard employee hiring and promotion practices. This information can be obtained from a typical HRM textbook as well as from recommendations from The European Community Regional Development Fund (http://www.equality-online.org.uk/equality_advice /recruitment_selection.html) and EEOC's Best Practices of Private Sector Employers (http://govinfo.library.unt.edu/npr/library/Best-Practices.htm).

The above information may be delivered prior to assigning the case by using at least one (1) of the follow methods: 
- a short lecture, student presentation, discussion session, and/or reading assignments on aforementioned topics.

- a guest lecturer from a human resource manager and/or EEOC compliance officer.

Background information on the major Human Resource topics discussed in this case are embedded in the answers to the Suggested Case Questions.

\subsection{Role-Playing (50 minutes)}

Role-playing enacts a case and allows the students to explore the human, social, and political dynamics of a case situation. This case lends itself quite well to a role playing exercise since the filing of discrimination charges can be enacted through a confrontational venue; a mock court.

Prior to role-playing the case part, students should be asked to not only read the case part but to answer the following questions:

Who are the key participants in the case? Why?

What is the "role" of each of these participants in the organization?

What is their motivation or rationale for their behavior?

What is the dilemma that the character is facing and/or how can the character assist someone else in solving a problem?

The instructor may either go through these questions prior to case enactment or wait for the role playing exercise to be completed in order to use this material to debrief the class.

Step 1: Assignment of Roles \& Instructions (10 minutes). The class as a whole should be employed for this exercise and broken up into groups of 4-5 students. One student needs to play the role of Aida, the other role of Luke. The rest of the members of the group can be observers and, with time permitting, also enact the role play.

Step 2: Enactment (20 minutes). The instructor or the student playing the role of the Luke should start the conversation by summarizing the situation and then asking Aida if she would mind taking off her hijab while she canvassed in order to increase her opportunity to obtain donations. The instructions to Luke should be to at first be understanding of her religious practices but in the end insist that she either remove her hijab or obtain another job. He should site her very poor record of success to support his request. Aida, on the other hand, should insist on her religious need to wear her hijab and her right to do so at work. She should also point out that Amnesty International's mission is to support diversity and especially those people who do not have a voice. The student playing Aida should, if need be, threaten to go to his supervisor, to go to HR and to take legal action as needed.

Step 3: Debriefing (20 minutes). The instructor might want to ask the observers to answer the following questions:

1) What were the salient issues that arose?

2) What were the results of the roleplay? 
3) What legal actions could be taken by Aida given the results?

The instructor should then have the class as a whole comment on the results of the role-play and determine with the class their overall analysis of the situation. Students should also be given the opportunity to comment on the role-playing exercise as a learning instrument. The instructor might ask the class the following questions:

Did this exercise animate the case? Did students get a "feel" for the issues surrounding the issue of symbols at work? What were the strengths and weaknesses of the exercise? What changes would they make to the exercise given their experiences with it?

The debriefing session should produce closure for students by connecting HRM practices and EEOC laws with case specifics and the results of the role-playing exercise.

\section{Background Information}

\subsection{Discrimination in the Workplace}

Traditional college students, unless they have had some amount of experience in the work force, are usually quite surprised to learn that even in these so called enlightened times that discrimination is alive and unfortunately quite well in America, even in not-for-profit organizations who mission might be humanitarian in nature.

There has been undeniable progress in many areas. Nevertheless, the evidence is overwhelming that the problems affirmative action seeks to address -- widespread discrimination and exclusion and their ripple effects -- continue to exist.

Minorities and women remain economically disadvantaged: the black unemployment rate remains over twice the white unemployment rate; 97 percent of senior managers in Fortune 1000 corporations are white males; in 1992, 33.3 percent of blacks and 29.3 percent of Hispanics lived in poverty, compared to 11.6 percent of whites. In 1993, Hispanic men were half as likely as white men to be managers or professionals; only 0.4 percent of senior management positions in Fortune 1000 industrial and Fortune 500 service industries are Hispanic.

Blatant discrimination is a continuing problem in the labor market. Perhaps the most convincing evidence comes from "audit" studies, in which white and minority (or male and female) job seekers are given similar resumes and sent to the same set of firms to apply for a job. These studies often find that employers are less likely to interview or offer a job to minority applicants and to female applicants.

Less direct evidence on discrimination comes from comparisons of earnings of blacks and whites, or males and females. Even after adjusting for characteristics that affect earnings (such as years of education and work experience), these studies typically find that blacks and women are paid less than their white male counterparts. The average income for Hispanic women with college degrees is less than the average for white men with high school degrees. (Anonymous, 2006)

Discrimination also occurs in many forms and with various nuances. "Title VII of the Civil Rights Act of 1964 protects workers from employment discrimination based on their race, color, religion, sex, national origin, opposition to practices made unlawful by Title VII, or 
participation in Title VII proceedings." (Dominguez, 2002) The Office of the High Commissioner for Human Rights of the United Nations noted that discrimination included discrimination based upon HIV/AIDS, religious intolerance, people with disabilities, migrant workers, xenophobia, and racial discrimination. (Anonymous, n.d., 5). The International Labour Office concurred with the United Nations and noted that many people suffer from multiple discrimination. (Anonymous, n.d., 3)

One of the purposes of this case is to present to students a situation where discrimination is not only present but would appear counter to the resolve of the organization. It is also a cautionary tale. An organization may espouse equality, empowerment and management, but failure to train, execute and enforce these discrimination policies may have substantial repercussions.

\section{Suggested Case Questions}

Discerning the real problem in the case could serve as an introductory question (i.e. discuss the problem posed in the case), however, this question should be separated from the other case-specific questions dealing with spercific human resource management issues since it is evident that the latter questions would bias the answer to the first question. We suggest that, at most, students be given only the question dealing with the role playing exercise as a take home assignment and that the remainder of the questions be employed as in-class discussion questions.

\section{What is your opinion as to Aida's approach to job searching? What would you have done in her place?}

According to the case, Aida decided that she should take a different approach to job searching and try to find and organization that fit her values and philosophy as well as an organization that would be quite sensitive to her religious orientation and needs. She surfed the internet looking for what she characterized as her "dream" organization. Rather than finding the right job at the right place and at the right time, she opted to find a cultural and mission fit.

Cultural fit is the likelihood that someone will reflect and/or be able to adapt to the core beliefs, attitudes, and behaviors that make up your organization. And a 2005 analysis revealed that employees who fit well with their organization, coworkers, and supervisor had greater job satisfaction, were more likely to remain with their organization, and showed superior job performance. ... Culture fit is the glue that holds an organization together. That's why it's a key trait to look for when recruiting. The result of poor culture fit due to turnover can cost an organization between 50-60\% of the person's annual salary, according to the Society for Human Resource Management (SHRM). But before the hiring team starts measuring candidates' culture fit, they need to be able to define and articulate the organization's culture - its values, goals, and practices - and then weave this understanding into the hiring process. (Bouton, 2015)

There is no one right way to search for a job so a student's description of how Aida should have searched is purely opinion. However, most career coaches agree that some methods definitely pay off better than others do, and that is where applicants need to invest their time 
and energy. The best strategies combine new technologies -- such as the growth of social networking sites -- with the idea of making personal connections to potential employers, and preparing to follow up if they do not respond right away.

a. Cold Calling. If your circle is small, you are probably better off approaching key decision-makers directly by email, phone or social networking site messages. Commonly known as cold calling, this technique focuses on getting the decision-maker's attention with a customized communication. In fact, the first contact should come by email, which is a non-disruptive introduction. Give your potential employer a week to respond; then follow up by a different method, such as a phone call.

b. Hidden Job Market. By some estimates, about half of all jobs are filled before the public sees them online, according to "U.S. News \& World Report." This phenomenon is called the hidden job market. Cracking that market requires building relationships with major decision-makers -- such as department heads, for example -- to learn who's hiring, or who's leaving. To make this strategy work, you must reach beyond friends, who tend to have the same job market knowledge as you do.

c. Networking. Reaching out to employers through people that you know remains one of the most effective job searching methods. According to "Forbes" magazine, the best results mix online searches with an old school personnel approach. For example, you can use social network sites like LinkedIn to identify people with some connection to the company you are approaching. Through personalized emails and phone calls, you ask to mention your contacts to a potential employer -- or, better yet, put in a good word on your behalf.

d. Resume Keywords. Employers are increasingly using keyword-searchable databases to speed up the task of reviewing resumes. Your resume, then, must contain keywords that relate to the job you are seeking, according to Quintessential Careers. You should then list an accomplishment showing how you used a skill related to each keyword -- which will lift you above candidates who simply list job duties and responsibilities. Without the right keywords, there is little chance that an employer will ever find you. (Heibutzki, n.d.)

2. If Aida received a personality test based upon the "Big Five" theory of personality, where do you think she would score highest/lowest? Is her personality a good "fit" for a canvasser? Why or why not.

Aida's and Luke are both apprehensive as to whether or not Aida's personality is a good fit for the job. Some experts estimate that as many as 60 percent of workers are now asked to take workplace assessments. The $\$ 500$-million-a-year industry has grown by about 10 percent annually in recent years. While many organizations use personality testing for career development, about 22 percent use it to evaluate job candidates, according to the results of a 2014 survey of 344 Society for Human Resource Management members. However, there are thousands of personality assessments available, and their quality varies. Some might even land an employer in legal trouble. So HR professionals should explore their options carefully before deciding whether a personality assessment is right for their company and, if so, which one to use. Even after careful selection of an assessment, they shouldn't rely solely on the test results when making hiring decisions. 
Compared to other hiring selection practices, personality assessments are among the least effective in predicting job performance, according to research by Frank L. Schmidt, management and organizations professor emeritus at the University of Iowa. He found that they work best when they are combined with other measures, such as cognitive ability or integrity tests, that have a higher predictive validity.

However, Deniz S. Ones, professor of industrial psychology at the University of Minnesota, Twin Cities, believes that a well-designed personality assessment, if used properly, can be a useful and accurate way to gauge if someone will be a good fit. The problem is that not all tests are created equal, she says. "A good test, just like a good car, would have withstood strenuous technical tests, just like a dummy crash." (Meinert, 2015)

Research has indicated that there is a correlation between personality and performance. Many assessments are based on the Five Factor Model, which consists of openness to experience, conscientiousness, extroversion, agreeableness and neuroticism. Those assessments have been subject to the most evaluation by researchers. Among them is conscientiousness a personality traits demonstrated to be good predictor for job performance. Personality tests have been criticized because some might fake their response on the test (Rao, 2013). Students may disagree as to whether Aida is openness to experience, conscientiousness, agreeable and neurotic yet it is clear that she lacked self-confidence given her prior job interview experiences. Coupled with her lack of success as a canvasser she would probably score lower in this category than in the others. Whether she is a good fit or not for a canvasser's job, it is recommend that the "preferred traits," include optimism, presence, confidence, curiosity, and assertiveness. You want a determined, thick-skinned, "manageable maverick" who can act autonomously, work at a fast pace, and maintain eye contact. (Yoho, 2014)

Some students might indicate that a personality test might in some way conflict with Amnesty's values and mission statement. Others might signify that these traits must be part of the canvasser's job description - the major tasks, duties, and responsibilities that are components of a job (Lussier \& Hendon, 2014).

3. Examine the summary, responsibilities, education, experience and skills required for a canvasser (Appendix 2). Do you agree that these are appropriate for a canvasser? Does Aida fit the current job description/specification? If you disagree, what would propose and why?

Job Analysis is a primary tool to collect job-related data. The process results in collecting and recording two data sets including job description and job specification. Any job vacancy cannot be filled until and unless Human Resource manager has these two sets of data. It is necessary to define them accurately in order to fit the right person at the right place and at the right time. This helps both employer and employee understand what exactly needs to be delivered and how. Both job description and job specification are essential parts of job analysis information. Writing them clearly and accurately helps organization and workers cope with many work-related challenges. 


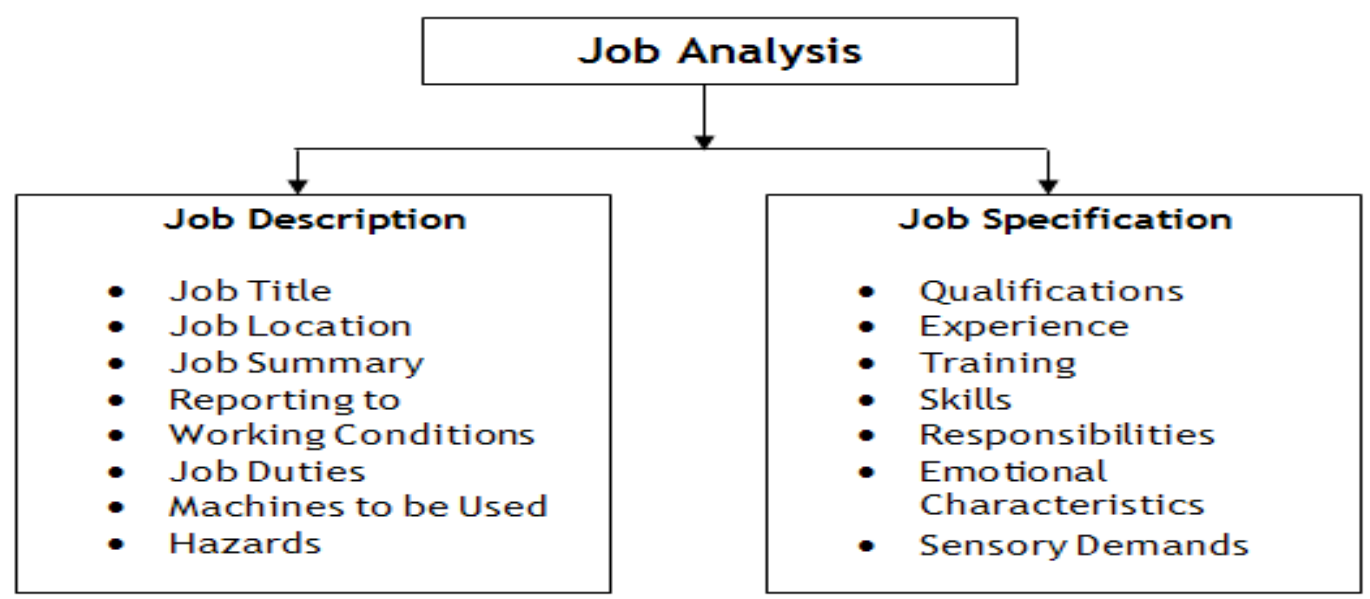

Figure 1. Job Analysis: Job Description and Job Specification

(https://www.managementstudyguide.com/job-description-specification.htm, 2/6/18)

Though preparing job description and job specification are not legal requirements, they play a vital role in getting the desired outcome. These data sets help in determining the necessity, worth and scope of a specific job. A job description includes basic job-related data that is useful to advertise a specific job and attract a pool of talent. It includes information such as job title, job location, reporting to and of employees, job summary, nature and objectives of a job, tasks and duties to be performed, working conditions, machines, tools and equipment to be used by a prospective worker and hazards involved in it. The main purpose of job description is to collect job-related data in order to advertise for a particular job. It helps in attracting, targeting, recruiting and selecting the right candidate for the right job. It is done to determine what needs to be delivered in a particular job. It clarifies what employees are supposed to do if selected for that particular job opening. It gives recruiting staff a clear view what kind of candidate is required by a particular department or division to perform a specific task or job. It also clarifies who will report to whom.

Also known as employee specifications, a job specification is a written statement of educational qualifications, specific qualities, level of experience, physical, emotional, technical and communication skills required to perform a job, responsibilities involved in a job and other unusual sensory demands. It also includes general health, mental health, intelligence, aptitude, memory, judgment, leadership skills, emotional ability, adaptability, flexibility, values and ethics, manners and creativity, etc. Described based on job description, job specification helps candidates analyse whether they are eligible to apply for a particular job vacancy or not. It helps the recruiting team of an organization understand what level of qualifications, qualities and set of characteristics should be present in a candidate to make him or her eligible for the job opening. Job Specifications give detailed information about any job including job responsibilities, desired technical and physical skills, conversational ability and much more. Further, it helps in selecting the most appropriate candidate for a particular job. (Anonymous, n.d., 4)

As listed in Appendix 2 of the case, the job description/specification for a canvasser is as follows: 
Summary: Our canvassers persuade the general public to support Amnesty International USA's (AIUSA) mission. Canvassers work in public spaces informing people about our work and inspiring them to support us as members. ...

\section{Responsibilities \\ - $\quad$ Distribute information about Amnesty International's mission. \\ - $\quad$ Represent a positive image of AIUSA to the public.}

\section{Requirements Education and Experience:}

Roles requiring strong communication skills a plus.

-

Sales experience good, but not required.

Skills:

Strong interpersonal skills

Positive energy and attitude

Interest/passion for human rights issues and AIUSA's mission

Motivated and driven

Note that the first problem is that nowhere in the summary job description or in list of responsibilities does the description of the job include actual cold call soliciting on the street for donations. The term 'support us as members' could be interpreted to mean non-economic support, support via use of telemarketing, following up on prospects (leads), or giving speeches in either public or private venues. Secondly, the listed responsibilities are quite vague and does not describe how to the applicant will distribute information nor represent AIUSA. Job Hero recommends the following job description for a canvasser:

Engage in face-to-face cold calling to acquire clients for organizations such as WGVU
or political campaigns. Learn the important information and history of the organizations
supported to deliver messages persuasively through door-to-door canvassing and gain
donations and support. Collect financial and demographic information of donors
including cash, checks, and credit card info. Take extra steps to further increase
potential client base by educating those not currently ready to donate about the value of
the organization and leaving supplied creative literature on how future support can be
given. Report all findings back to accounting department daily including performance
meeting daily goals, average donations, and bringing new sustaining members into the
organization. (http://www.jobhero.com/resume-samples /canvasser\#, n.d.)

Third, education, work experience and related skills must be correlated to the job to be performed. There are no educational requirements listed and one would suppose some education would be required to both understand and communicate AI's mission. The same could be said about cold call canvassing. Though sales experience is 'good', it is not required and once again, one would think that prior experience would be warranted given the difficulties of the job. Skills listed for the job seem to focus on "soft skills" and the need for a "passion" for AIUSA's mission. MyMajors recommends the following skills, knowledge and working style for this position: 
Importance

Importance

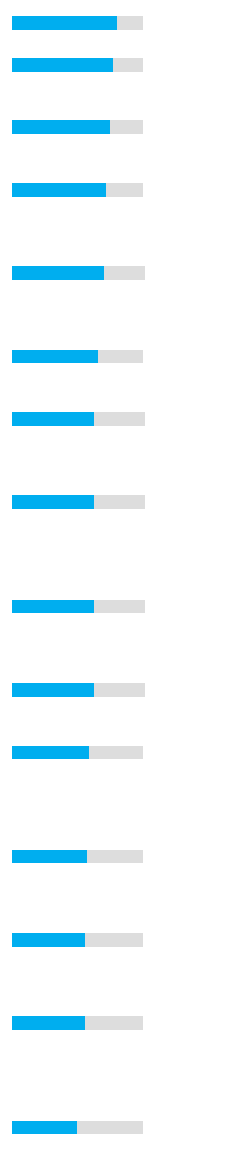

\section{Importance}
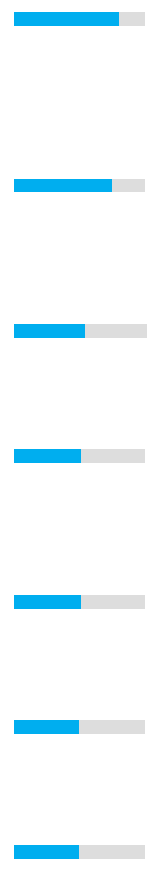

Speaking - Talking to others to convey information effectively.

Persuasion - Persuading others to change their minds or behavior.

Social Perceptiveness - Being aware of others' reactions and understanding why they react as they do.

Service Orientation - Actively looking for ways to help people.

Active Listening - Giving full attention to what other people are saying, taking time to understand the points being made, asking questions as appropriate, and not interrupting at inappropriate times.

Coordination - Adjusting actions in relation to others' actions.

Reading Comprehension - Understanding written sentences and paragraphs in work related documents.

Writing - Communicating effectively in writing as appropriate for the needs of the audience.

Critical Thinking - Using logic and reasoning to identify the strengths and weaknesses of alternative solutions, conclusions or approaches to problems.

Negotiation - Bringing others together and trying to reconcile differences.

Judgment and Decision Making - Considering the relative costs and benefits of potential actions to choose the most appropriate one.

Monitoring - Monitoring/Assessing performance of yourself, other individuals, or organizations to make improvements or take corrective action.

Time Management - Managing one's own time and the time of others.

Complex Problem Solving - Identifying complex problems and reviewing related information to develop and evaluate options and implement solutions.

Active Learning - Understanding the implications of new information for both current and future problem-solving and decision-making.

\section{Knowledge}

Sales and Marketing - Knowledge of principles and methods for showing, promoting, and selling products or services. This includes marketing strategy and tactics, product demonstration, sales techniques, and sales control systems.

Customer and Personal Service - Knowledge of principles and processes for providing customer and personal services. This includes customer needs assessment, meeting quality standards for services, and evaluation of customer satisfaction.

Education and Training - Knowledge of principles and methods for curriculum and training design, teaching and instruction for individuals and groups, and the measurement of training effects.

English Language - Knowledge of the structure and content of the English language including the meaning and spelling of words, rules of composition, and grammar.

Communications and Media - Knowledge of media production, communication, and dissemination techniques and methods. This includes alternative ways to inform and entertain via written, oral, and visual media.

Mathematics - Knowledge of arithmetic, algebra, geometry, calculus, statistics, and their applications.

Clerical - Knowledge of administrative and clerical procedures and systems such as word processing, managing files and records, stenography and transcription, designing forms, and other office procedures and terminology. 


\section{Importance}

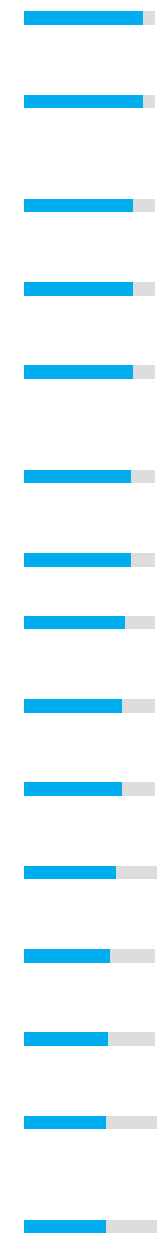

Working Styles

Integrity - Job requires being honest and ethical.

Independence - Job requires developing one's own ways of doing things, guiding oneself with little or no supervision, and depending on oneself to get things done.

Dependability - Job requires being reliable, responsible, and dependable, and fulfilling obligations.

Initiative - Job requires a willingness to take on responsibilities and challenges.

Cooperation - Job requires being pleasant with others on the job and displaying a good-natured, cooperative attitude.

Self Control - Job requires maintaining composure, keeping emotions in check, controlling anger, and avoiding aggressive behavior, even in very difficult situations.

Persistence - Job requires persistence in the face of obstacles.

Achievement/Effort - Job requires establishing and maintaining personally challenging achievement goals and exerting effort toward mastering tasks.

Concern for Others - Job requires being sensitive to others' needs and feelings and being understanding and helpful on the job.

Social Orientation - Job requires preferring to work with others rather than alone, and being personally connected with others on the job.

Adaptability/Flexibility - Job requires being open to change (positive or negative) and to considerable variety in the workplace.

Attention to Detail - Job requires being careful about detail and thorough in completing work tasks.

Leadership - Job requires a willingness to lead, take charge, and offer opinions and direction.

Innovation - Job requires creativity and alternative thinking to develop new ideas for and answers to work-related problems.

Stress Tolerance - Job requires accepting criticism and dealing calmly and effectively with high stress situations. (https://www.mymajors.com/career/canvasser/skills/, 2/8/18)

Given the above analyses, students should conclude that the job description and job specification are inadequate in describing the position of canvasser. Given an insufficient job description/specification, it is not surprising that most students would conclude that although Aida may have the knowledge and desire to work as a canvasser that she evidently lacks the personality (extroversion) and sales experience in which to perform well on the job. Canvassers need to be able to deal with stress associated with rejection and ridicule and being persistent in the face of these obstacles.

\section{Discuss the legal and moral issues surrounding symbols of faith at work. Can Luke legally ask Aida to take off her hijab? Regardless of legalities, how would this action fit in with AI USA's mission?}

According to report from the Society of Human Resource Management (SHRM), 64 percent of organizations identified they had a diverse religious workforce in 2008, which was an increase from a prior 2001 study of only $36 \%$ (Rao, 2013). When it comes to employment law, religion is the fastest growing and most confusing area according to Gregg (n.d). The US Equal Opportunity Employment Office has issued the following re: religious garb in the workplace.

Examples of religious dress and grooming practices include: wearing religious clothing or articles (e.g., a Muslim hijab (headscarf), a Sikh turban, or a Christian 
cross); observing a religious prohibition against wearing certain garments (e.g., a Muslim, Pentecostal Christian, or Orthodox Jewish woman's practice of not wearing pants or short skirts), or adhering to shaving or hair length observances (e.g., Sikh uncut hair and beard, Rastafarian dreadlocks, or Jewish peyes (sidelocks)). In most instances, employers are required by federal law to make exceptions to their usual rules or preferences to permit applicants and employees to observe religious dress and grooming practices. (US EEOC, n.d. "Religious Garb and Grooming in the Workplace: Rights and Responsibilities", https://www.eeoc.gov/eeoc/publications/qa_religious_garb_grooming.cfm, 2/1/18).

The negative consequences of workplace discrimination can be divided into three types: fines, litigation costs and bad publicity (Mayhew, 2010). If there is evidence that discrimination has occurred, the EEOC, The U.S Department of Labor, Office of Federal Contract Compliance Programs and Wage and Hour Division have all congressional authorities to impose fines and penalties (Mayhew, 2010). In addition to litigation costs (attorney fees, investigative expenses), the employer might have to pay all attorney fees including the plaintiff's attorney fees (Mayhew, 2010). On top of that, there may be decreased sales and revenue because of media coverage (Mayhew, 2010).

The team leader, Luke, is clearly conflicted about the fact that Aida is wearing a hijab and its impact on her performance as a canvasser. He is planning to bring this up for discussion yet it seems clear he is neither familiar with the legal issues surrounding the wearing of religious symbols nor how his employer AIUSA might react to such actions.

According to the U.S Equal Employment Opportunity Commission, the law forbids discrimination when it comes to any aspect of employment and that the harasser can for instance be the victim's supervisor, such as Luke the team leader in this case (Religious Discrimination n.d.). An employer must reasonably accommodate an employee's religious beliefs, which also includes wearing particular head coverings (Religious Discrimination n.d.). It is also clear that Luke is also not aware that his actions are counter to AIUSA values of diversity and inclusion at the workplace because their overall philosophy is valuing differences including Aida wearing a hijab ("Employment/Internship", n.d). If he actually did broach this subject with her Aida she might respond negatively to this request and go over his head to his supervisor. Worse, she potentially could sue Amnesty International for religious discrimination.

\section{What is negligent hiring and how does it apply to this case? How reliable are background checks in reducing negligent hiring?}

Rao (2013) defines negligent hire as when an employer hires an applicant without checking his or her background and subsequently the applicant causes harm to their co-workers or customers. Negligent hiring claims are preventable if employers do their job that is to ensure that employees and customers have a well-organized, safe work environment. In this work environment, people have a right to a reasonable expectation that they will not be injured or harmed. Customers have the right to the same expectation as employees. 
At the end of the case, it becomes apparent that there has been a negligent hire. Holly is stealing money from the donors by asking them to pay a \$20 cash membership fee, which she has made up, and pockets the cash. She is also aware that if they had conducted a background check she in all likelihood would not have gotten the job. According to Prior (2017), Amnesty did not conduct background checks in the hiring process. This is also evident from their homepage where they only ask for a reference from recent employer, preferably two, and that they will not approach the references without permission (Amnesty International, n.d). Holly has obviously submitted references that would not or could not warn Amnesty about her behavior. Amnesty's responsibility is to avoid negligent hiring by conducting background checks (Rao, 2013). They should also make sure to have more structured interviews where they probe applicants about their past work accomplishments, education, and references and employ a reliable background check service to verify the given information. In this case, Amnesty is liable for negligent hiring by not exercising appropriate background checking activities that have revealed the employee's propensity for harming coworkers or customers.

However, according to Lademeji (2014), employment references have the lowest predictive validity of all the major forms of candidate assessment - e.g., structured interviews, testing, work samples - according to studies from Beardwell at al. in 2004 and CIPD in 2007. Yet, at the time of the studies, over half of employers relied on references. This percentage is likely to have increased since then, because social media has made background checking much easier. Studies suggest that around 90 percent of employers conduct social media background checks today.

Employers to avoid negligent hiring need to perform the following actions.

- Do a criminal background check on potential employees, ("The April 25, 2012, Enforcement Guidance issued by the EEOC takes the position that an employer's use of an individual's arrest or conviction records in making employment decisions will violate Title VII in some circumstances, according to L. Diane Tindall, Attorney-at-Law. Employers need a strictly followed policy that examines criminal records on a case-by-case basis and to consult an attorney.)

- Check employment and personal references.

- Check employment history and attempt to speak with former supervisors.

- Validate college degrees'

- Perform drug screening in particular industries including potentially hazardous manufacturing jobs.

- Require physicals in some occupations including such jobs as truck driving or any job that entails a lot of strenuous physical activity.

- Perform credit checks for some jobs especially those involving money.

- Check driving records and history for some occupations including truck driving and any job that requires the use of company cars or machinery. 
- Confirm that other claims made by the applicant, such as why he left a prior employer, why he had a two-year employment gap, why he worked at four companies in two years, and so forth, are true. (Heathfield, 2017)

\section{Concluding Comments}

AIUSA is facing at least two major HR issues, potential discrimination of religious beliefs (assuming Luke actually does have that discussion with Aida about her attire) and negligent hire. Luke will eventually have to discuss both situations with his supervisor Mr. Clark and it will be Mr. Clark's responsibility to then handle both situations. AIUSA needs to learn from this experience and evaluate their existing recruitment and hiring procedures to ensure that they hire the right people (right skills and right values) that fits both the job requirements and the firm's mission.

\section{References}

Anonymous (n.d., 1). Canvasser Career. MyMajors. https://www.mymajors.com /career/canvasser/skills/, 2/8/18.

Anonymous (n.d., 2). Canvasser Resume Samples. JOBHERO. http://www.jobhero. com/resume-samples/canvasser\#, 2/8/18.

Anonymous (n.d., 3). Forms of Discrimination. International Labour Office, Retrieved from http://www.ilo.org/dyn/declaris/DECLARATIONWEB.DOWNLOAD_

BLOB?Var_DocumentID=1632, September 29, 2006.

Anonymous (n.d., 4). Job Description and Job Specification. Management Study Guide. https://www.managementstudyguide.com/job-description-specification.htm, 2/6/18.

Anonymous (n.d., 5). Other Forms of Discrimination. United Nations High Commissioner for Human Rights. Retrieved from http://www. unhchr.ch/html/menu2 /issother.htm, September 29, 2017.

Byars, L., \& Rue, L. (2006). Human Resource Management. 8th Edition. New York: McGraw-Hill Higher Education

DuBrin, A. J. (2006). Essentials of Management. 7th Edition. Mason, OH: Thomson South-Western.

Employment/Internship Opportunities with Amnesty International USA. (n.d.). https://careers.aiusa.org/, 4/28/2017.

Jones, G. R. and J. M. George (2006). Contemporary Management. 4th Edition. New York: McGraw-Hill Irwin.

Gregg, R. E. (n.d.). Religion in the Workplace. Boardman \& Clark. http:// www.boardmanclark.com/reading-room/religion-in-the-workplace, 2/17/17.

Heibutzki, R. (n.d.). The Best Job Search Methods. Chron. http://work.chron.com/job-searchmethods-15211.html, 2/5/18. 
Kleinman, L (2004). Human Resource Management: A Managerial Tool for Competitive Advantage. 3rd Edition. Cincinnati, $\mathrm{OH}$ : Atomic Dog Publishing.

Lussier, R. N., \& Hendon, J. R. (2014). Human Resource Management: Functions, Applications, and Skill Development. SAGE Publications. Kindle Edition.

Marketing Methods. (n.d.). https://gogo.promogogo.com/words/marketing-methods, 4/28/17.

Rao, P. (2013). Taking sides. New York: McGraw-Hill.

Religious Discrimination. (n.d.). https://www.eeoc.gov/laws/types/religion.cfm, 4/28/17.

Who We Are. (n.d.). http://www.amnestyusa.org/about-us/who-we-are, 4/28/17.

Dominguez, C. M. (December 2, 2002). EEOC Compliance Manual. The U.S. Equal Employment Opportunity Commission. Number 915.003, Section 13-1.

Anonymous (September 29, 2006). The Justification for Affirmative Action: The Continuing Need to Combat Discrimination and Promote Inclusion. http://clinton2. nara.gove/wh/eop/op/html/aa/aa04.html, September 2, 2017.

Logo Amnesty International logo design. (2008, June 15). http://www.logodesignlove. com/amnesty-international-logo-design, 4/28/17.

Mayhew, R. (2010, June 24). What Are the Consequences of Discrimination on the Job? http://smallbusiness.chron.com/consequences-discrimination-job-1312.html, 4/28/17.

Yoho, D. A. (2014, August 12). 8 Key Ingredients to a Successful Canvassing Program. Pro Remodeler. https://www.proremodeler.com/blog/8-key-ingredients-successfulcanvassing-program, 2/6/18.

Meinert, D. (2015, June 1). What Do Personality Tests Really Reveal? Personality assessments are being used more often in the hiring process. Are they accurate? Society for Human Resource Management, https:/www.shrm.org/hr-today/news/hr-magazine/ Pages/0615-personality-tests.aspx, 2/5/18.

Bouton, K. (2015, July 17). Recruiting for Cultural Fit. Harvard Business Review. https://hbr.org/2015/07/recruiting-for-cultural-fit, 2/6/18.

Amnesty International. (n.d.). Retrieved April 28, 2017, https://www.amnesty.org/en/ careers/faqs/.

Heathfield, S. M. (2017, Oct. 12). What Are Negligent Hiring Claims? When Might an Employee or Customer Make a Negligent Hiring Claim? The Balance. https://www. thebalance.com/what-are-negligent-hiring-claims-1918018, 2/5/18.

Lademeji, K. (2017, Oct. 17). How to Get Reliable Information from Reference Checks. Recruiter. $\quad$ https://www.recruiter.com/i/how-to-get-reliable-information-from -reference-checks/, 2/8/2018. 


\section{Copyright Disclaimer}

Copyright for this article is retained by the author(s), with first publication rights granted to the journal.

This is an open-access article distributed under the terms and conditions of the Creative Commons Attribution license (http://creativecommons.org/licenses/by/4.0/). 